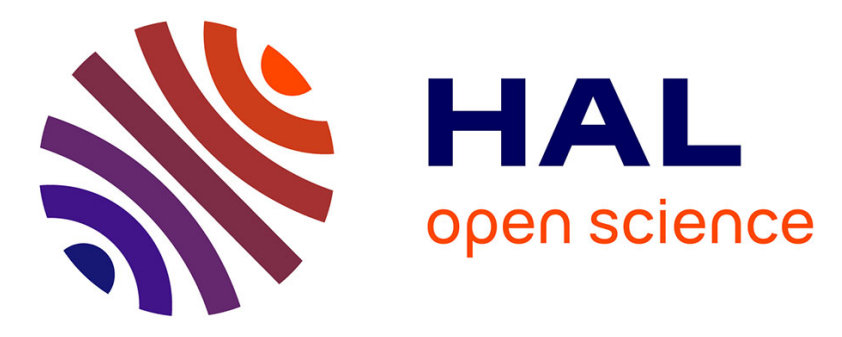

\title{
EKT Open Book Press: A case study for a successful institutional publishing initiative
}

Irakleitos Souyioultzoglou, Marina Angelaki, Kostas Stamatis

\section{To cite this version:}

Irakleitos Souyioultzoglou, Marina Angelaki, Kostas Stamatis. EKT Open Book Press: A case study for a successful institutional publishing initiative. ELPUB 2019 23rd edition of the International Conference on Electronic Publishing, Jun 2019, Marseille, France. 10.4000/proceedings.elpub.2019.5 . hal-02175185

\section{HAL Id: hal-02175185 \\ https://hal.science/hal-02175185}

Submitted on 5 Jul 2019

HAL is a multi-disciplinary open access archive for the deposit and dissemination of scientific research documents, whether they are published or not. The documents may come from teaching and research institutions in France or abroad, or from public or private research centers.
L'archive ouverte pluridisciplinaire HAL, est destinée au dépôt et à la diffusion de documents scientifiques de niveau recherche, publiés ou non, émanant des établissements d'enseignement et de recherche français ou étrangers, des laboratoires publics ou privés. 


\section{EKT Open Book Press}

A case study for a successful institutional publishing initiative

Irakleitos Souyioultzoglou, Marina Angelaki and Kostas Stamatis

\section{The National Documentation Centre's role in promoting open scholarly communication in Greece}

1 The National Documentation Centre (EKT) plays a central role in the collection and dissemination of scientific and cultural content in Greece and beyond, through the application of integrated workflows for the aggregation, validation and publication of open access digital sources generated by diverse communities of practice. ${ }^{1}$ The aim of this paper is to present Open Book Press (OBP), ${ }^{2}$ an electronic publishing platform developed by EKT and provided to non-profit institutional publishers (scholarly societies, research centres, Universities) for the publication of digital-born SSH monographs and edited volumes.

Open Book Press is a component of ePublishing EKT, ${ }^{3}$ a suite of publishing infrastructures and complementary services dedicated to the dissemination of open access, peerreviewed scientific output. ePublishing EKT represents a comprehensive publication management approach based on the introduction of optimal editorial and content dissemination workflows, as well as a successful open access business model that provides -at no cost- services to scientific institutions, thus enabling them to actively participate in the digital scholarly communication ecosystem. ePublishing EKT inaugurated in 2007, as part of a project for the development of institutional digital infrastructures (e.g. repositories, publishing platforms) supported by the European Union/ European Regional Development Fund and the Greek state, within the framework of the Operational Program "Digital Convergence".. The main focus of the project was to facilitate the introduction of digital scholarly communication models in the Greek academic community, by providing a spectrum of related resources, services and platforms that enabled the migration of high-quality scholarly publications into a digital ecosystem as well as the implementation of digitally-oriented publication processes. 
ePublishing EKT has gradually evolved into a horizontal publishing service offered at national level to non-profit institutional publishers. Open Book Press was launched as part of this wider project, stemming from the importance of monographs in the $\mathrm{SSH}$, as well as the potential of electronic publishing infrastructures to serve as an effective dissemination medium of scholarly publications using a minority language. Besides OBP, ePublishing EKT deploys two platforms that currently host 35 non-APC peer reviewed journals, ${ }^{5}$ and 4 series of conference proceedings. ${ }^{6}$

\section{The Open Book Press electronic publishing platform}

OBP deployment is based on a collaborative model that facilitates the transition to digital publishing: EKT provides the electronic infrastructure and support (training, editorial consulting, technical support, publicity, helpdesk) for the standardization of content publishing and indexing workflows. Publishers introduce content quality processes (e.g. submission guidelines, internal and external peer-review) and monitor authors' compliance with standards that ensure originality and scientific adequacy of published content.

OBP abides to a spectrum of principles inherent to the concept of bibliodiveristy, as it adopts a long-term sustainable approach oriented towards the complementarity of engaged parts' contribution: offered at a national level and to non-profit institutions, OBP enables initiatives by agents with otherwise limited access to the mainstream publishing industry. Moreover, it contributes to the adoption of the Open Science paradigm at national level, as well as the dissemination of high quality SSH content in Greek.

Additionally, OPB deploys a technically efficient publishing model: the integrated publishing environment operates with open source software (PKP's Open Monograph Press) ${ }^{7}$ and is regularly updated with new functionalities and tools developed by the PKP's global community of users. In addition, OMP is interoperable with other platforms, research and harvesting infrastructures, thus allowing content indexing and wide dissemination.

7 The selection of this open source publishing platform is closely intertwined with EKT's commitment to engage in collaborative initiatives towards the enhancement of open scholarly communication. EKT actively contributes to the development of OMP: under the EU funded project HIRMEOS, ${ }^{8}$ OMP was extended to support identification services and assign unique identifiers to publications (DOI) and contributors (ORCID). Additional developments in the context of HIRMEOS relate to the platform's integration with the DOAB certification system for peer review processes, a system that provides altmetrics (OAMetrics) and citation measurements, as well as an entity fishing system that automatically recognizes tag named entities in monographs (NERD).

EKT's participation in HIRMEOS is an instance of the institution's innovative operational framework, which funnels structural funds into a robust infrastructure, developmental initiatives and cloud-native digital services, with a scope to aggregate, curate and publish a growing volume of open access digital content. The applied business model is further leveraged by EKT's engagement in European consortiums (e.g. the OPERAS network for scholarly communication in the $\mathrm{SSH})^{9}$ and EU-funded projects related to digital infrastructures and Open Science. Thus, EKT serves as facilitator of inclusive and open circulation of knowledge in and for society, at local and European level. 
EKT's project-oriented approach enables the institution to commit efforts in developmental initiatives that multiply the impact of received funding, as in the case of the HIRMEOS project, where all technical implementations have been applied to OBP and became available to the wider OMP user community. On the other hand, this funding scheme poses challenges to long-term sustainability: The service is provided at no cost, as collaborating publishers' capacity to contribute is rather limited and further curtailed by their responsibility to cover costs related to the production of the digital publications. To overcome funding fragmentation, particular emphasis is given on seeking alternative resources and applying collaborative business models that will diversify fund flows and enable OBP's sustainable growth in the future.

The project's initial funding of $€ 25,000$ was received in the context of the Operational Program "Digital Convergence" and was subsequently channeled to an open call for the publication of SSH monographs by institutional academic publishers. Upon completion of this pilot, publication costs are covered by collaborating publishers through a variety of funding schemes (participation in research projects resulting in publication of monographs, structural funding, research grants to affiliated personnel etc.). On EKT's side, operating costs have been significantly reduced by the standardization of services and workflows that render EKT ePublishing fully operational with the support of two affiliates from the institution's technical and administrative teams, respectively.

\section{Conclusion}

11 OBP is a successful initiative with reciprocal benefits for engaged parts and the wider SSH community in Greece. It serves as a source of peer reviewed content and supports EKT in its role as a national node for the collection of scientific output, while collaborating publishers transition to online publishing venues and comply with the requirements of research funders for open access to publications. Moreover, this innovative initiative render Greek publications and scholarship more relevant to the international scholarly community and enhance the promotion of SSH literature produced using a minority language in Academia.

\section{NOTES}

1. National Documentation Centre: www.ekt.gr.

2. Open Book Press: http://ebooks.epublishing.ekt.gr/

3. ePublishing EKT: http://epublishing.ekt.gr/

4. Nafpliotis, A., V. Tsoukala, N. Houssos, A. Kalaitzis, and E. Sachini. 2014. "EKT ePublishing: Developing an open access publishing service for the Greek research community,18th International Conference on Electronic Publishing. Let's put data to use: digital scholarship for the next generation." In Proceedings of the 18th International Conference on Electronic Publishing (Ebook), pp. 112-118. Netherlands: IOS Press BV. http://helios-eie.ekt.gr/EIE/ handle/10442/14317 
5. eJournals EKT: https://ejournals.epublishing.ekt.gr/

6. eProceedings EKT: https://eproceedings.epublishing.ekt.gr/

7. Open Monograph Press: https://pkp.sfu.ca/omp/

8. EU project HIRMEOS: https://www.hirmeos.eu/

9. OPERAS network: https://operas.hypotheses.org/

\section{ABSTRACT}

The aim of this paper is to present Open Book Press (OBP), an electronic publishing platform for monographs, developed by the National Documentation Centre (EKT). Focus is placed on OBP's open access business model and services that enable the wide dissemination of high quality scientific output in Greek.

\section{INDEX}

Keywords: scholarly communication, electronic pudlishing, collaborative publishing models, Open Access, Open Book Press

\section{AUTHORS}

\section{IRAKLEITOS SOUYIOULTZOGLOU}

National Documentation Centre

irakleitos@ekt.gr

MARINA ANGELAKI

National Documentation Centre

KOSTAS STAMATIS

National Documentation Centre 